\title{
Impact of Genotype, Planting Date, Plant Density and Inflorescence Type on Bee Abundance and Seed Production in Broccoli
}

\author{
Soliman M. Kamel ${ }^{1}$; Khalid E. Abd El-Hamed ${ }^{2}$; Kariman M. Mohamed ${ }^{1 *}$ and Manal M. Masoud $^{1}$ \\ ${ }^{1}$ Department of Plant Protection, Faculty of Agriculture, Suez Canal University, Ismailia, Egypt \\ ${ }^{2}$ Department of Horticulture, Faculty of Agriculture, Suez Canal University, Ismailia, Egypt
}

\section{Received: $2 / 6 / 2014$}

\begin{abstract}
Field experiment was conducted in 2011-2012 to study the impact of genotype, planting date, and inflorescence type on bee abundance and seed production of broccoli in Ismailia Governorate. The abundance of two selected bee species, Apis mellifera L. and Colletes lacunatus Dours was estimated on two cultivars of broccoli, Sultan and Marathon in two different planting dates and two types of inflorescences (primary and secondary). Results indicated that both $A$. mellifera and $C$. lacunatus significantly increased the pollination percentage. Bee abundance was significantly at the maximum level at $11.00 \mathrm{am}-1.00 \mathrm{pm}$, all over the weeks of observation, followed by the previous time of observation, at 9.00-11.00 am, then decreased significantly at 1.00-3.00 pm to reach the lowest abundance 3.00$5.00 \mathrm{pm}$. Also, results indicated that C. lacunatus was the dominant pollinator and had more intensity visitation than $A$. mellifera on the both cultivars. Generally, Marathon tends to give more fruit number and weight and accordingly more seeds of light weight. On the other hand, Sultan has a tendency to give less seed number of heavier weight. The primary inflorescence gave less number of flowers and consequently less number of fruits than secondary inflorescence, but those fewer fruits gave less number of seeds with heavier weight. The effect of planting density on seed production was due to differences in number and destination of transported pollen grains. Planting date showed a profound influence on the potential of seed yield. This study demonstrated that bee pollination could significantly improve both the yield and the quality of seeds in broccoli under Ismailia conditions.
\end{abstract}

Keywords: Broccoli, pollination, seed production, bee abundance.

\section{INTRODUCTION}

As a result of cross pollination by bees, hybrid effects induce several favorable qualitative and quantitative changes in the economic and biological aspects of the plants. It can stimulate germination of pollen on stigma of flower, increase number and size of seeds and yield of crops, increase fruit set and finally reduce fruit drop. Interaction of wild pollinators and honeybees seems to enhance yield (Greenleaf and Kremen, 2006a). The domesticated honeybee, $A$. mellifera L. has been utilized to provide managed pollination systems, but for many crops, honeybees are either not effective or are suboptimal pollinator (Westerkamp, 1991). Pollination services provided by wild biodiversity may be of key importance (Klein et al., 2003).

Cultivated species of Brassica are very attractive to insects especially honeybees. Flies (Syrphidae, Calliphorinae, Muscidae) and small beetles are occasional visitors (Free and Williams, 1973). Honey bees were the most frequent visitors on kale (Brassica oleracea var. acephala L.) compared to bumble bees (mainly Bambus terrestris (L.), B. lapidaries (L.) and other wild bees (Mesquida, 1978).

The impact of honeybee pollination on the seed production of the three Brassica vegetables, Brassica oleacea var. italica, B. rapa pekinensis and B. oleracea var. gongylodes, and the pollination behaviour of $A$. mellifera was studied by Sushil et al. (2013) who found that honeybees played an important role in enhancing the seed production of all the crops under study. Honeybee pollination was also found to inflict maximum impact on the seed production of broccoli, with an increase in seed yield. Foraging activity of the honeybees $A$. cerana and $A$. mellifera significantly

Corresponding author e-mail: karimanmm@yahoo.com increased the percent pollination (siliqua set) (Devkota et al., 2003).

The present investigation was undertaken to study the effect of two cultivars of broccoli, planting date, and inflorescence type on attracting bee pollinators, as well as their impact on seed production and yield components of broccoli.

\section{MATERIALS AND METHODS}

Plant material and growth conditions:

Field experiment was conducted at the Experimental Research Farm, Faculty of Agriculture, Suez Canal University, Ismailia, Egypt during the period from autumn of 2011 till spring of 2012. The experimental area of about one feddan (feddan $=4200 \mathrm{~m}^{2}$ ) was prepared three months before transplanting. The experiment was designed in a randomized complete block design with three replicates of each treatment. The studied broccoli cultivars were Sultan" (As grow Seed Company, USA), and "Marathon" (Sakata Seed America Inc., USA). Seeds of broccoli genotype were sown in 209-cell Styrofoam trays under greenhouse conditions. After emerging, Broccoli seedlings, four weeks old, were transplanted in the field, from the end of November 2011 to the end of May, 2012. The experiment included two planting densities (4200 and 8400 plants per feddan), two planting dates; early (mid-October) and late (end of October) and tow type of inflorescences (primary and secondary).

The primary heads started to be formed after 3 months of planting, and then needed to about 3-4 weeks to turn into primary inflorescences. To get the secondary inflorescences; some of the primary heads were cut and needed to about 1-2 weeks to form the newly heads and about 5 days to be turned into secondary inflorescences. 
Abundance of bee pollinators:

The foraging activity of the both selected bees, Apis mellifera and Colletes lacunatus on broccoli inflorescences was observed once every week starting after 5\% flowering (7-8 weeks after transplanting) till the final session, throughout four time intervals of the day; 9.00-11.00 am, $11.00 \mathrm{am}-1.00 \mathrm{pm}, 1.00-3.00 \mathrm{pm}$ and $3.00-5.00 \mathrm{pm}$. Observation time of visiting pollinators was about five minutes for each time interval in each treatment selected randomly at one square meter. The numbers of visiting bees of each species were counted using electronic stopwatch, voice recorder and digital video camera.

\section{Broccoli seed productivity:}

Several parameters were measured to determine the effect of genotype, planting date, inflorescence type and plant density on broccoli seed production. Fruit numbers per plant, weight of 100 fruits and weight of 100 seeds were recorded. Seeds counting and weighing (using a digital scale) were carried out after harvest. Seeds were collected in maturation phase when the silique fruits were completely dry.

\section{Statistical analysis:}

Data obtained from bees foraging activities, quantitative and qualitative parameters were statistically analyzed through ANOVA. When F-test was significant, means were separated using Duncan's test at the 0.05 level of significance.

\section{RESULTS}

\section{Effect on bee abundance:}

Comparative abundance of the two selected pollinators indicated that C. lacunatus bees was the predominant pollinator, with averages of 2.68 and 2.86 bees $/ 5$ min on early and late plantings of Marathon cultivar, respectively. The corresponding figures were 1.88 and $2.64 \mathrm{bees} / 5 \mathrm{~min}$. on early and late plantings of Sultan cultivar.

On the other hand, A. mellifera was represented by the averages of 2.14 and 1.97 on early and late plantings of Marathon cultivar, opposed to 2.61 and 2.4 bees/5 min on early and late plantings of Sultan cultivar, respectively (Table 1).

Results in Table (2) indicated that the secondary inflorescences were more attractive to both bee species than the primary one. The intensity of bee visitors on secondary inflorescences being represented by 2.58 and $2.66 \mathrm{bees} / 5 \mathrm{~min}$ on early and late plantings of Marathon cultivars, and 2.61 and 2.83 bees $/ 5$ min on early and late planting dates of Sultan cultivars, respectively. While, the respective averages of the intensity of both bee species on primary inflorescences were 2.25 and 2.17 bees/ 5 min on early and late plantings of Marathon cultivar, opposed to 1.88 and 2.21 on early and late plantings of Sultan cultivars (Table 2).

Also, all over the observed weeks, the second week of each treatment showed the most abundance of bees in both cultivars and also in both planting dates, with respective averages of 2.73 and $2.59 \mathrm{bees} / 5 \mathrm{~min}$ on early and late planting Marathon cultivar, opposed to the representing figures of 2.06 and 2.78 bees $/ 5 \mathrm{~min}$ for Sultan cultivars. However, in early planting Sultan cultivar, the highest number of bee visitations $(2.73$ bees $15 \mathrm{~min}$ ) was recorded in the fourth week (Table 2).

Table (1): Effects of cultivar and planting date on the abundance of bee species visiting broccoli flowers

\begin{tabular}{cccccc}
\hline & \multicolumn{4}{c}{ Cultivars and Planting Date } \\
\cline { 2 - 6 } Bee species & \multicolumn{4}{c}{ Marathon } & \multicolumn{3}{c}{ Sultan } \\
\cline { 2 - 6 } & $\begin{array}{c}\text { Early } \\
\text { Planting Date }\end{array}$ & $\begin{array}{c}\text { Late } \\
\text { Planting Date }\end{array}$ & $\begin{array}{c}\text { Early } \\
\text { Planting Date }\end{array}$ & $\begin{array}{c}\text { Late } \\
\text { Planting Date }\end{array}$ \\
\hline C. lacunatus & $2.68 \mathrm{a}$ & $2.86 \mathrm{a}$ & $1.88 \mathrm{~b}$ & $2.64 \mathrm{a}$ & $2.4 \mathrm{~b}$ \\
A. mellifera & $2.14 \mathrm{~b}$ & $1.97 \mathrm{~b}$ & $2.61 \mathrm{a}$ & \\
\hline
\end{tabular}

Table (2): Comparative effects between cultivar and planting date, inflorescence type, bee species, weeks, and time of observation on bee abundance on broccoli

\begin{tabular}{|c|c|c|c|c|c|}
\hline \multirow{3}{*}{ Factor } & & \multicolumn{4}{|c|}{ Cultivars and Planting Date } \\
\hline & & \multicolumn{2}{|c|}{ Marathon } & \multicolumn{2}{|c|}{ Sultan } \\
\hline & & $\begin{array}{c}\text { Early } \\
\text { Planting Date }\end{array}$ & $\begin{array}{c}\text { Late } \\
\text { Planting Date }\end{array}$ & $\begin{array}{c}\text { Early } \\
\text { Planting Date }\end{array}$ & $\begin{array}{c}\text { Late } \\
\text { Planting Date }\end{array}$ \\
\hline \multirow{6}{*}{$\begin{array}{c}\text { Weeks of } \\
\text { Observation }\end{array}$} & W1 & $2.28 \mathrm{~b}$ & $2.5 \mathrm{a}$ & $1.81 \mathrm{~d}$ & $2.31 \mathrm{~b}$ \\
\hline & W2 & $2.73 \mathrm{a}$ & $2.59 \mathrm{a}$ & $2.06 \mathrm{c}$ & $2.78 \mathrm{a}$ \\
\hline & W3 & $2.28 \mathrm{~b}$ & $2.52 \mathrm{a}$ & $2.42 \mathrm{~b}$ & $2.36 \mathrm{~b}$ \\
\hline & W4 & $2.33 \mathrm{~b}$ & $2.05 \mathrm{~b}$ & $2.73 \mathrm{a}$ & $2.70 \mathrm{a}$ \\
\hline & W5 & $2.44 \mathrm{~b}$ & - & $2.53 \mathrm{ab}$ & $2.44 \mathrm{~b}$ \\
\hline & W6 & - & - & $1.92 \mathrm{~cd}$ & - \\
\hline \multirow{2}{*}{$\begin{array}{c}\text { Inflorescences } \\
\text { type }\end{array}$} & Primary & $2.25 \mathrm{~b}$ & $2.17 \mathrm{~b}$ & $1.88 \mathrm{~b}$ & $2.21 \mathrm{~b}$ \\
\hline & secondary & $2.58 \mathrm{a}$ & $2.66 \mathrm{a}$ & $2.61 \mathrm{a}$ & $2.83 \mathrm{a}$ \\
\hline \multirow{4}{*}{$\begin{array}{c}\text { Times of } \\
\text { Observation }\end{array}$} & $9.00-11.00 \mathrm{am}$ & $2.98 \mathrm{~b}$ & $3.03 \mathrm{~b}$ & $2.61 \mathrm{~b}$ & $3.14 \mathrm{a}$ \\
\hline & $11.00 \mathrm{am}-1.00 \mathrm{pm}$ & $3.34 \mathrm{a}$ & $3.38 \mathrm{a}$ & $3.01 \mathrm{a}$ & $3.34 \mathrm{a}$ \\
\hline & $1.00-3.00 \mathrm{pm}$ & $2.24 \mathrm{c}$ & $2.20 \mathrm{c}$ & $2.21 \mathrm{c}$ & $2.46 \mathrm{~b}$ \\
\hline & $3.00-5.00 \mathrm{pm}$ & $1.1 \mathrm{~d}$ & $1.05 \mathrm{~d}$ & $1.15 \mathrm{~d}$ & $1.14 \mathrm{c}$ \\
\hline
\end{tabular}


Observations also showed that bee abundance reached its maximum during the mid day at $11.00 \mathrm{am}$ $1.00 \mathrm{pm}$, compared to the rest intervals, with averages of 3.34 and 3.38 bees $/ 5$ min on early and late plantings of Marathon cultivar and 3.01 and 3.34 bees $/ 5 \mathrm{~min}$. on early and late plantings of Sultan cultivar, respectively.

The bee visitation in the morning at 9.00-11.00 am ranked secondary with respective averages of 2.98 , and $3.30 \mathrm{bees} / 5 \mathrm{~min}$. on early and late plantings of Marathon cultivar, opposed to respective count of 2.61 and 3.14 bees/5 min in Sultan cultivar. However, bee visitation decreased significantly at the other two time intervals through the observation day (Table 2).

Data presented in Table (3) revealed highly significant effects on bee abundance were existence for each single factor, as the effect of different observed weeks, the four times of observations, the two species of bees and the two kinds of inflorescences on different planting dates and cultivars.
Also, there are highly significant interaction effects of each two factors on bee abundance such as the interaction between weeks of observation and kind of inflorescences, as well as between weeks and bee species. However, no significant differences were observed at the cases of the interactions between other studied factors (Table 3 ).

Concerning the interaction between three studying factors, there was a highly significant difference between different weeks of observation, the two types of inflorescences and the two species of bees. While there were no significant differences between different weeks of observation, both types of inflorescences and the four times of observation, as well as between both types of inflorescences, both species of bees and the four times of observations.

In respect of the interaction between four factors, there were no significant differences between different weeks of observation, both types of inflorescences, both species of bees and the four time intervals (Table 3 ).

Table (3): The interaction effects between inflorescence type, bee species, weeks, and time of observation of broccoli

\begin{tabular}{|c|c|c|c|c|}
\hline \multirow[b]{2}{*}{ Factor } & \multicolumn{2}{|c|}{ Marathon } & \multicolumn{2}{|c|}{ Sultan } \\
\hline & $\begin{array}{c}\text { Early } \\
\text { Planting Date }\end{array}$ & $\begin{array}{c}\text { Late } \\
\text { Planting Date }\end{array}$ & $\begin{array}{c}\text { Early } \\
\text { Planting Date }\end{array}$ & $\begin{array}{c}\text { Late } \\
\text { Planting Date }\end{array}$ \\
\hline Weeks & $* * *$ & $* * *$ & $* * *$ & $* * *$ \\
\hline Inflorescence & $* * *$ & $* * *$ & $* * *$ & $* * *$ \\
\hline Weeks* Inflorescence & $* *$ & $* * *$ & ns & $* * *$ \\
\hline Bee species & $* * *$ & $* * *$ & $* * *$ & $* *$ \\
\hline Weeks*Bee species & $* * *$ & $* * *$ & $* * *$ & $* * *$ \\
\hline Inflorescence* Bee species & ns & $*$ & ns & ns \\
\hline Weeks* Inflorescence*Bee species & $* *$ & $* * *$ & $* * *$ & $* * *$ \\
\hline Time & $* * *$ & $* * *$ & $* * *$ & $* * *$ \\
\hline Weeks*Time & ns & $*$ & $* * *$ & $* *$ \\
\hline Inflorescence*Time & $* *$ & $* * *$ & $*$ & ns \\
\hline Weeks*Inflorescence*Time & ns & $* *$ & ns & ns \\
\hline Bee species*Time & ns & ns & $* * *$ & ns \\
\hline Weeks*Bee species*Time & ns & ns & $* * *$ & $* *$ \\
\hline Inflorescence*Bee species*Time & ns & $* *$ & ns & ns \\
\hline Weeks*Inflorescence*Bee species*Time & $*$ & ns & ns & ns \\
\hline
\end{tabular}

\section{Effect on broccoli seed productivity:}

Data presented in Table (4) showed the main effect of genotype, planting date, inflorescence type and plant density on broccoli fruit and seed production. Results indicated significant affect of genotype on the most of the studied traits. Genotype Marathon showed significantly higher number and 100 fruits weight than Sultan. However, both genotypes showed insignificant differences concerning seed weight although Sultan genotype showed higher weight by $45 \%$ (Table 4 ).

Planting date only affected the weight of broccoli fruits since the early planting date showed higher weight when compared with late planting date. On the other hand, both fruit number and seed weight was not significantly affected by planting date. The obtained results of early planting gave higher fruit number while late planting gave higher seed weight (Table 4).

Broccoli main heads (flowers) were left to produce raceme inflorescence (primary) while the other group of plants was harvested. Harvesting promote the plants to produce secondary inflorescences from axillary floral buds. The inflorescence type significantly affected the number and weight of silique fruits. The secondary inflorescence gave both higher number and weight of fruits than primary inflorescence. There was no significant difference concerning the seed weight, however primary inflorescence gave relatively higher seed weight (Table 4).

The variation on planting density did not have significant effect on the broccoli seed production. However, the low number of broccoli plants in unit area that was associated with the low number of planting population gave higher number and weight of broccoli fruits while increasing the plants in unit area gave higher seed weight (Table 4).

Table (5) representing the interaction effect between different factors under study and the number of broccoli fruits. Results suggested that the highest fruit number was obtained when genotype Marathon was used with secondary inflorescence in the first (early) planting date and high plant population (812.25 silique/plant). 
Table (4): The main effect of genotype, planting date, inflorescence type and plant density on broccoli fruit and seed production

\begin{tabular}{|c|c|c|c|c|}
\hline Factor & & Fruit Number & 100 Fruits Weight (g.) & $\begin{array}{c}100 \text { Seeds Weight } \\
\text { (g.) }\end{array}$ \\
\hline \multirow{2}{*}{ Genotype } & Sultan & $525.22 \mathrm{~b}$ & $9.02 \mathrm{~b}$ & $0.82 \mathrm{a}$ \\
\hline & Marathon & $666.12 \mathrm{a}$ & $9.90 \mathrm{a}$ & $0.45 \mathrm{a}$ \\
\hline \multirow{2}{*}{ Planting Date } & Early & $607.94 \mathrm{a}$ & $9.04 \mathrm{~b}$ & $0.47 \mathrm{a}$ \\
\hline & Late & $583.44 \mathrm{a}$ & $9.88 \mathrm{a}$ & $0.81 \mathrm{a}$ \\
\hline \multirow{2}{*}{ Inflorescence Type } & Primary & $510.66 \mathrm{~b}$ & $8.80 \mathrm{~b}$ & $0.75 \mathrm{a}$ \\
\hline & Secondary & $680.72 \mathrm{a}$ & $10.12 \mathrm{a}$ & $0.52 \mathrm{a}$ \\
\hline \multirow{2}{*}{ Plant Density } & High & $583.44 \mathrm{a}$ & $9.10 \mathrm{a}$ & $0.71 \mathrm{a}$ \\
\hline & Low & $607.94 \mathrm{a}$ & $9.82 \mathrm{a}$ & $0.57 \mathrm{a}$ \\
\hline
\end{tabular}

Table (5): The interaction effect between genotype, planting date, inflorescence type and plant density on broccoli fruit number

Genotype

\begin{tabular}{|c|c|c|c|c|c|}
\hline \multirow[b]{3}{*}{ Inflorescence Type } & \multirow[b]{3}{*}{ Plant Density } & \multirow{2}{*}{\multicolumn{2}{|c|}{ Sultan }} & & \\
\hline & & & & \multicolumn{2}{|c|}{ Marathon } \\
\hline & & $\begin{array}{c}\text { Early Planting } \\
\text { Date }\end{array}$ & $\begin{array}{c}\text { Late Planting } \\
\text { Date }\end{array}$ & $\begin{array}{c}\text { Early Planting } \\
\text { Date }\end{array}$ & $\begin{array}{c}\text { Late Planting } \\
\text { Date }\end{array}$ \\
\hline \multirow{2}{*}{ Primary } & High & $406.50 \mathrm{hi}$ & $395.5 \mathrm{i}$ & 495 fghi & $621.25 \mathrm{cde}$ \\
\hline & Low & 517.25 efgh & 458.75 ghi & 626.75 bcde & $564.25 \mathrm{defg}$ \\
\hline \multirow{2}{*}{ Secondary } & High & 637 bcde & $552.5 \mathrm{defg}$ & $812.25 \mathrm{a}$ & $747.50 \mathrm{ab}$ \\
\hline & Low & $644.5 \mathrm{bcd}$ & $589.75 \mathrm{def}$ & $724.25 \mathrm{abc}$ & $738 \mathrm{abc}$ \\
\hline
\end{tabular}

Table (6) representing the interaction effect between different factors under study and the weight of broccoli fruits. Results suggested that the highest fruit weight was obtained when genotype Marathon was used with secondary inflorescence in the first (early) planting date and high plant population (11.48 gram/100 silique).

Table (7) representing the interaction effect between different factors under study and the weight of broccoli seed. Results suggested that the highest seed weight was obtained when genotype Sultan was used with primary inflorescence in the second (late) planting date and high plant population (2.35 gram/100 seed).

Statistical analysis in Table (8) showed significance level of main and interaction effect between genotype, planting date, inflorescence type and plant density on broccoli fruit and seed production. Data indicated that the effect of each factor was statistically isolated from other factors which showed that genotypes and inflorescences type significantly affected most of the studied fruits and seeds traits, while all interactions between different factors had no significant differences (Table 8).

Table (6): The interaction effect between genotype, planting date, inflorescence type and plant density on broccoli 100 fruits weight (g.)

\begin{tabular}{lccccc}
\hline & & \multicolumn{3}{c}{ Genotype } \\
\cline { 3 - 6 } & & \multicolumn{2}{c}{ Sultan } & \multicolumn{2}{c}{ Marathon } \\
\hline Inflorescence Type & Plant Density & $\begin{array}{c}\text { Early Planting } \\
\text { Date }\end{array}$ & $\begin{array}{c}\text { Late Planting } \\
\text { Date }\end{array}$ & $\begin{array}{c}\text { Early Planting } \\
\text { Date }\end{array}$ & $\begin{array}{c}\text { Late Planting } \\
\text { Date }\end{array}$ \\
\hline \multirow{2}{*}{ Primary } & High & $6.25 \mathrm{~d}$ & $9.5 \mathrm{abc}$ & $6.88 \mathrm{~cd}$ & $9.3 \mathrm{abc}$ \\
& Low & $7.93 \mathrm{bcd}$ & $9.45 \mathrm{abc}$ & $11.23 \mathrm{a}$ & $9.88 \mathrm{ab}$ \\
\hline \multirow{2}{*}{ Secondary } & High & $9.43 \mathrm{abc}$ & $9.6 \mathrm{ab}$ & $11.48 \mathrm{a}$ & $10.35 \mathrm{ab}$ \\
& Low & $10 \mathrm{ab}$ & $10.03 \mathrm{ab}$ & $9.13 \mathrm{abc}$ & $10.95 \mathrm{a}$ \\
\hline
\end{tabular}


Table (7): The interaction effect between genotype, planting date, inflorescence type and plant density on broccoli 100 seeds weight (g.)

\begin{tabular}{lccccc}
\hline & & \multicolumn{4}{c}{ Genotype } \\
\cline { 3 - 6 } & & \multicolumn{2}{c}{ Sultan } & \multicolumn{2}{c}{ Marathon } \\
\hline \multirow{2}{*}{ Inflorescence Type } & Plant Density & $\begin{array}{c}\text { Early Planting } \\
\text { Date }\end{array}$ & $\begin{array}{c}\text { Late Planting } \\
\text { Date }\end{array}$ & $\begin{array}{c}\text { Early Planting } \\
\text { Date }\end{array}$ & $\begin{array}{c}\text { Late Planting } \\
\text { Date }\end{array}$ \\
\hline \multirow{2}{*}{ Primary } & High & $0.3 \mathrm{~b}$ & $2.35 \mathrm{a}$ & $0.38 \mathrm{~b}$ & $0.4 \mathrm{~b}$ \\
& Low & $0.35 \mathrm{~b}$ & $1.38 \mathrm{ab}$ & $0.43 \mathrm{~b}$ & $0.45 \mathrm{~b}$ \\
\hline \multirow{2}{*}{ Secondary } & High & $0.8 \mathrm{~b}$ & $0.48 \mathrm{~b}$ & $0.53 \mathrm{~b}$ & $0.45 \mathrm{~b}$ \\
& Low & $0.48 \mathrm{~b}$ & $0.45 \mathrm{~b}$ & $0.48 \mathrm{~b}$ & $0.53 \mathrm{~b}$ \\
\hline
\end{tabular}

Table (8): The significance level of main and interaction effect between genotype, planting date, inflorescence type and plant density on broccoli fruit and seed production

\begin{tabular}{|c|c|c|c|}
\hline Factor & Fruit Number & 100 Fruits Weight & 100 Seeds Weight \\
\hline Genotype (G) & $* * *$ & $*$ & ns \\
\hline Planting Date (D) & $\mathrm{ns}$ & $*$ & $\mathrm{~ns}$ \\
\hline Inflorescence Type (I) & $* * *$ & $* *$ & ns \\
\hline Plant Density ( $\mathbf{P}$ ) & ns & ns & ns \\
\hline G x D & ns & ns & ns \\
\hline Gx I & ns & $\mathrm{ns}$ & $\mathrm{ns}$ \\
\hline D x I & ns & ns & $*$ \\
\hline $\mathbf{G} \times \mathbf{P}$ & ns & ns & ns \\
\hline $\mathbf{D} \times \mathbf{P}$ & ns & ns & ns \\
\hline $\mathbf{I} \times \mathbf{P}$ & $\mathrm{ns}$ & $*$ & $\mathrm{~ns}$ \\
\hline$G \times D \times I$ & ns & ns & $*$ \\
\hline$G \times D \times P$ & ns & ns & ns \\
\hline$G \times I \times P$ & ns & ns & ns \\
\hline $\mathbf{D} \times \mathbf{I} \times \mathbf{P}$ & $*$ & $*$ & ns \\
\hline$G \times D \times I \times P$ & ns & ns & ns \\
\hline
\end{tabular}

\section{DISCUSSION}

The results of comparative and interaction studies between all factors affecting the bees visitation, showed that $C$. lacunatus was the dominant pollinator and had more intensity visitation than A. mellifera on the both cultivars, Marathon and Sultan at the early and late planting dates, except at the early planting date of Sultan cultivar.

Results were in agreement with Hussein and AbdelAal (1982) who mentioned that honeybee pollination was limited for radish, wormwood, carrot and grasses. Also, Robertson (1922) found that wild bees were more efficient pollinators than the honey bees since they visit more flowers per unit of time.

Additional experiments showed that single flower visits from rare solitary species led to higher fruit set than with abundant social species (Klein et al., 2003), while Garibaldi et al. (2013) found universally positive associations of fruit set with flower visitation by wild insects in 41 crop systems worldwide. In contrast, fruit set increased significantly with flower visitation by honey bees in only $14 \%$ of the systems surveyed.

However, more studies still needed on the role of wild bee pollination of different crops which can be a good alternative of honey bee pollination (Greenleaf and Kremen, 2006b). However, the contribution of wild bees remains unmeasured for many crops. Klein et al. (2003) mentioned that for nine crops, empirical studies showed evidence that wild pollinators contributed to successful pollination without similar evidence for honeybees, and for six (atemoya, cocoa, fig, passion fruit, oil palm and sapodilla) of these nine crops honeybees were not mentioned as pollinators.

Also results indicated that the abundance of both bees was more on the secondary inflorescences in the both cultivars, Marathon and Sultan in both planting dates. That may be due to the abundance of the flowers of the secondary inflorescences, which had more branches and flowers than primary ones. Concerning times of observation, the intensity of visitation of both bee species was at the maximum number at $11.00 \mathrm{am}-$ $1.00 \mathrm{pm}$ all over the observed weeks and at both 
cultivars and planting dates, followed by the time at $9.00-11.00$ am with significant differences. These results are in agreement with Verma and Partap (2010), Verma, and Phogat (1994), Verma, and Joshi (1983) who found that peak foraging activity of $A$. cerana on cauliflower and cabbage was between 11.00 am and $13.00 \mathrm{pm}$ for each crop.

Results in Tables $(4-8)$ revealed that broccoli plants that exposed to insect visits had a significant quantity and quality yield. Although some crops such as sesame can produce seeds without bee pollination, presence of pollinators is important to increase yields, and hence, food security and income. Similarly, bee pollination is essential for reproduction in the other (cross pollinated crops). In the present study, there was a significant increase in the quantity and quality of parameters in all treatments of opened pollination field.

Generally, Marathon genotype tends to give more fruit number and weight, and accordingly more seeds of light weight. On the other hand, Sultan genotype has a tendency to give less seed number of heavier weight. The performance of both genotypes included in this study was in the same line with their performance in previous studies (Abd El-Hamed and Elwan, 2010; Elwan and Abd El-Hamed, 2011). The effect of inflorescence on seed production has been studied by Wyatt (1982), who reported that inflorescence architecture can have direct physical effect on the rate and pattern of pollen movement with plant populations (Wyatt, 1982).

The obtained results concerning the effect of inflorescence type was logic and expected to some extent. The primary inflorescence gave less number of flowers and consequently less number of fruits than secondary inflorescence but those fewer fruits will gave less number of seeds with heavier weight. The effect of planting population on seed production has been reported in soybean (Weber et al., 1966; Ethredge et al., 1989) and bean (Crothers and Westermann, 1976). Our results concerning the effect of plant spacing on seed yield were also in constancy with previous results in soybean (Lehman and Lambert, 1960).

Planting date can have a profound influence on the potential of seed yield. It affects stand density, seedling development, weeds pressure, and eventually, yields. The effect of planting date on seed yield has been reported in Canola (Johnson et al., 1995; Ozer, 2003; Kirkland and Johnson, 2000), soybean (DeBruin and Pedersen, 2008), Brassica napus (Degenhardt and Kondra, 1981) and sunflower (Alessi et al., 1977).

The yield of rapeseed and mustard were doubled through pollination by insects. Pollinators not only enhance the yield of the crop but also contribute to uniform and early pod setting. Therefore, planned honeybee pollination could result in increased productivity and improvement in other parameters through the process of heterosis (Abrol, 2007a, b). Many cruciferous and leguminous flowers are unable to be fertilized by their own pollen and require pollen from another flower of the same species (cross-pollination). Cross-pollination was found to improve seed production even in self-fertile crops (Sihag, 1986, 1988).
The study indicated that both $A$. cerana and $A$. mellifera significantly increased the percent pollination (silique set) (Devkota et al., 2003). A. cerana pollination contributed in 480.11 and $24.21 \%$ increase in seed set per silique and naturally pollinated plants, whereas the percent increase in the seeds set per silique caused by $A$. mellifera pollination were 479.32 and $24.15 \%$ and naturally pollinated, respectively.

\section{REFERENCES}

Abrol, D. P. (2007a). Honeybees and rapeseed: a pollinator-plant interaction. Advances in Botanical Research, 45, 337-367.

Abrol, D. P. (2007b). Foraging behaviour of Apis mellifera and Apis cerana as determined by the energetics of nectar production in different cultivars of Brassica campestris var. toria. J. Apic. Sci., 51(2): 5-10.

Alessi, J., J. F. Power and D. C. Zimmerman (1977). Sunflower yield and water use as influenced by planting date, population, and row spacing. Agronomy journal, 69(3): 465-469.

Crothers, S. E. and D. T. Westermann (1976). Plant population effects on the seed yield of Phaseolus vulgaris L. Agronomy Journal, 68(6): 958-960.

De Bruin, J. L. and P. Pedersen (2008). Effect of row spacing and seeding rate on soybean yield. Agronomy journal, 100(3): 704-710.

Degenhardt, D. F. and Z. P. Kondra (1981). The influence of seeding date and seeding rate on seed yield and yield components of five genotypes of Brassica napus. Canadian Journal of Plant Science, 61(2): 175-183.

Devkota, F. R., G. Upreti, R. B. Thapa, S. M. Shakya and U. Partap (2003). Impact of honeybee pollination on productivity and quality of broccoli seed under Chitwan condition. Journal of the Institute of Agriculture and Animal Science, 24: 85-89.

El-Hamed, A. and M. W. M. Elwan (2010). Genotype by environment interaction and phenotypic stability of yield and quality in broccoli (Barassica oleracea var. italica). J. Plant Production, Mansoura Univ, 1(6): 819-835.

Elwan, M. W. M. and K. A. El-Hamed (2011). Influence of nitrogen form, growing season and sulfur fertilization on yield and the content of nitrate and vitamin $\mathrm{C}$ of broccoli. Scientia Horticulturae, 127(3): 181-187.

Ethredge, W. J., D. A. Ashley and J. M. Woodruff (1989). Row spacing and plant population effects on yield components of soybean. Agronomy Journal, 81(6): 947-951.

Free, J. B. and I. H. Williams (1973). The pollination of hybrid kale (Brassica oleraceae L.). The Journal of Agricultural Science, 81(3): 557-559.

Greenleaf, S. S. and C. Kremen (2006a). Wild bees enhance honey bees' pollination of hybrid sunflower. Proceedings of the National Academy of Sciences, 103(37): 13890-13895.

Greenleaf, S. S. and C. Kremen (2006b). Wild bee species increase tomato production and respond 
differently to surrounding land use in Northern California. Biological Conservation, 133(1): 8187.

Hussein, M. H. and S. A. Abdel Aal (1982). Wild and honey bees as pollinators of 10 plant species in Assiut area. Zeitschriftfür Angewandte Entomologie, 93(1-5): 342-346.

Garibaldi, L. A., I. Steffan-Dewenter, R. Winfree, M. A. Aizen, R. Bommarco, S. A. Cunningham and A. M. Klein (2013). Wild pollinators enhance fruit set of crops regardless of honey bee abundance. Science, 339(6127): 1608-1611.

Johnson, B. L., A. A. Schneiter, K. R. McKay, B. K. Hanson and B. G. Schatz (1995). Influence of planting date on canola and crambe production. Journal of production Agriculture, 8(4): 594-599.

Kirkland, K. J. and E. N. Johnson (2000). Alternative seeding dates (fall and April) affect Brassica napus canola yield and quality. Canadian Journal of Plant Science, 80(4): 713-719.

Klein, A.-M., I. Steffan-Dewenter and T. Tscharntke (2003). Bee pollination and fruit set of Coffea arabica and C. canephora (Rubiaceae). Am. J. Bot. 90: 153-157.

Lehman, W. F. and J. W. Lambert (1960). Effects of spacing of soybean plants between and within rows on yield and its components. Agronomy Journal, 52(2): 84-86.

Mesquida, J. (1978). Observations on entomophilous pollination of a few pairs of single hybrids of fodder kale (Brassica oleracea L. var. acephala DC) in isolation for the production of double hybrid seeds. Apidologie, 9(4): 321-339.

Ozer, H. (2003). Sowing date and nitrogen rate effects on growth, yield and yield components of two summer rapeseed cultivars. European Journal of Agronomy, 19(3): 453-463.
Robertson, C. (1922). The sunflower and its insect visitors. Ecology, 3(1): 17-21.

Sihag, R. C. (1986). Insect pollination increases seed production in cruciferous and umbelliferous crops. J. Apic, Res., 25: 121-126.

Sihag, R. C. (1988). Characterization of the pollinators of cultivated cruciferous and leguminous crops of sub-tropical Hissar, India. Bee World, 69(4): $153-158$

Sushil, S. N., J. Stanley, N. K. Hedau and J. C. Bhatt (2013). Enhancing seed production of three Brassica vegetables by honey bee pollination in North-western Himalayas of India.Universal Journal of Agricultural Research, 1(3): 49-53.

Verma L. R. and U. Partap (2010). Foraging behavior of Apis cerana on cauliflower and cabbage and its impact on seed production. Journal of Apicultural Research, 33(4): 231-236.

Verma, S. K. and N. K. Joshi (1983). Studies on the role of honey bees in the pollination of cauliflower (Brassica oleracea var. botrytis). Indian Bee J., 45: 57-58.

Verma, S. K. and K. P. S. Phogat (1994). Impact of pollination by honey bee (Apis cerana) on yield of radish under valley condition of Himalayan hills. Indian Bee J., 45: 183-186.

Weber, C., R. M. Shibles and D. E. Byth (1966). Effect of plant population and row spacing on soybean development and production. Agronomy journal, 58(1): 99-102.

Westerkamp, C. (1991). Honeybees are poor pollinators-why? Plant Systematics and Evolution, 177(1-2): 71-75.

Wyatt, R. (1982). Inflorescence architecture: how flower number, arrangement, and phenology affect pollination and fruit-set. American Journal of Botany, 69: 585-594.

\section{تأثير التركيب الوراثى، وميعاد الزراعة، وكثافة النباتات، ونوع النورات على نشاط النحل وإنتاج البذور فى

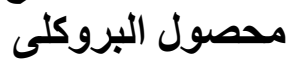

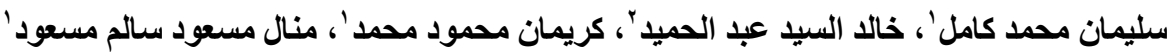

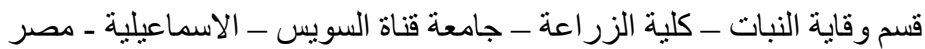

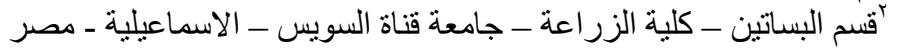

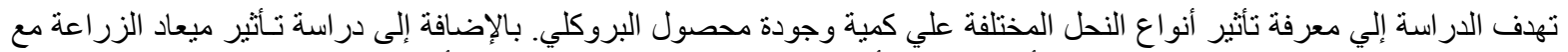

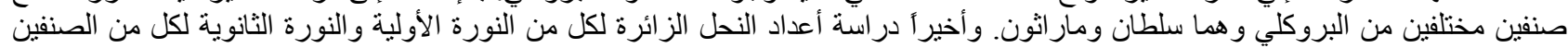

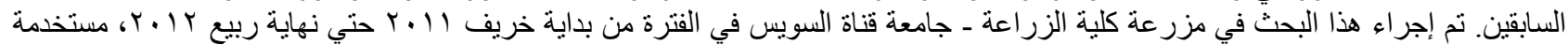

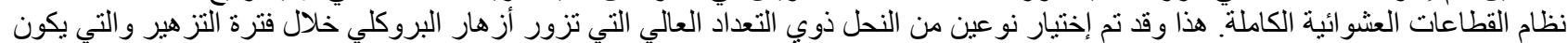

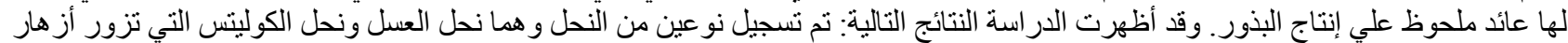

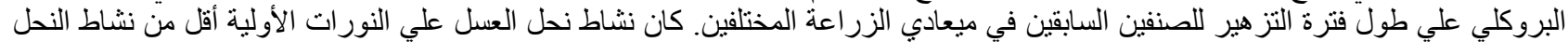

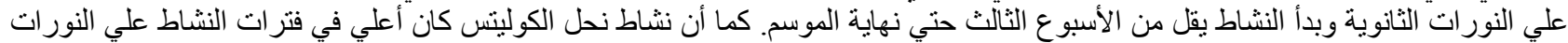

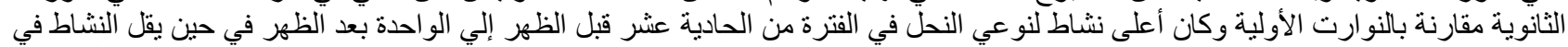

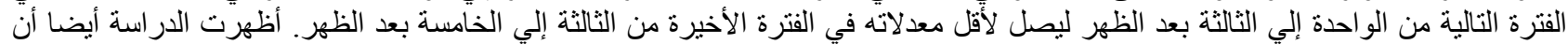

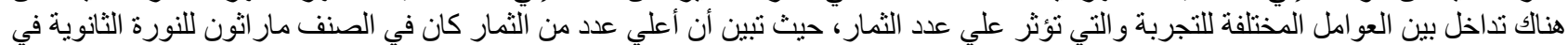

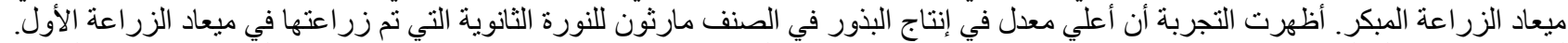

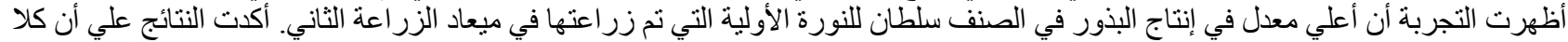

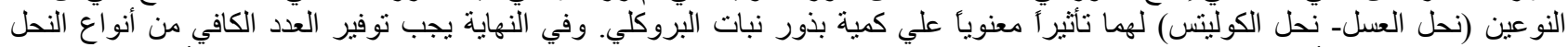

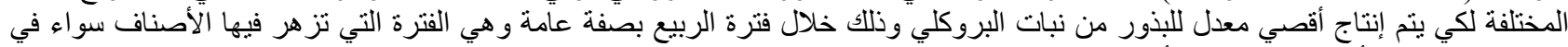

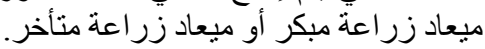

